\title{
Case 3847 - Simopithecus oswaldi Andrews, 1916 (currently Theropithecus oswaldi; Mammalia, Primates, Cercopithecidae), proposed conservation by reversal of precedence with Cynocephalus atlanticus Thomas, 1884
}

Eric Delson*

Lehman College, City University of New York, 250 Bedford Park Boulevard West, Bronx, NY 10468, USA.

(eric.delson@1ehman.cuny.edu)

David M. Alba

Institut Català de Paleontologia Miquel Crusafont, Universitat Autònoma de Barcelona, Edifici ICTA-ICP, Campus de la UAB, c/ Columnes, s/n, 08193 Cerdanyola del Vallès, Barcelona, Spain.

Stephen R. Frost

University of Oregon, Eugene, OR 97403-1218, USA.

Dagmawit Abebe Getahun

The Graduate Center, City University of New York, 365 Fifth Avenue, New York, NY 10016, USA.

Christopher C. Gilbert

Hunter College, City University of New York, 695 Park Avenue, New York, NY 10065, USA.

* Corresponding author

http://zoobank.org/urn:lsid:zoobank.org:pub:2E172321-E03C-435F-AF7E-F7979BF4A847

http://dx.doi.org/10.21805/bzn.v78.a026

\begin{abstract}
The purpose of this application, under Articles 23.9.3 and 81.1 of the Code, is to conserve the usage of the species-group name Simopithecus oswaldi Andrews, 1916 by giving it precedence over its senior subjective synonym Cynocephalus atlanticus Thomas, 1884. Theropithecus is a common to dominant member of the extinct primate community across Africa after 4 million years ago (Jablonski \& Frost, 2010) and often co-occurred with extinct humans (Hominini); fossils are also known rarely across Eurasia (Roberts et al., 2014). Most fossil samples are currently included in Theropithecus oswaldi (Andrews, 1916), which is often divided into chrono-geographic subspecies. Cynocephalus atlanticus Thomas, 1884 was not recognized as a member of Theropithecus until 1973, and this nomen has seldom been used, but if it were shown (as seems likely) to be conspecific with Simopithecus oswaldi Andrews, 1916, widespread paleontological usage would be
\end{abstract}


upset. It is thus proposed to give conditional precedence to the later name, which would still permit the use of Theropithecus atlanticus as a distinct species or subspecies of Theropithecus oswaldi. Lectotypes are designated for Simopithecus oswaldi olduvaiensis Leakey \& Whitworth, 1958 and Simopithecus oswaldi hopefieldensis Singer, 1962.

Keywords. Nomenclature; taxonomy; Mammalia; Primates; Cercopithecidae; Theropithecus; Africa; Eurasia; Pleistocene.

1. Thomas (1884: 14, pl. IV, fig. 4), in a description of fossil material recovered from the area of Constantine, Algeria, reported the presence of a single isolated lower molar (said to be last [third] but actually first or second) in the sandy conglomerate layer at Ain Jourdel. He stated (p. 14) that: «Ils ne sont représentés, jusqu'à présent, que par une seule arrière-molaire inférieure provenant du conglomérat gréseux d'Aïn-Jourdel (Planche IV, fig. 4). Cette dent, d'après M. A. Gaudry, qui a bien voulu l'examiner, indique un singe beaucoup plus grand que le Magot actuel d'Algérie; de plus, elle présente des caractères qui rappellent assez exactement ceux du Cynocephalus porcarius, Desm., actuellement relégué dans l'Afrique australe. Nous désignerons ce singe, provisoirement tout au moins, sous le nom de Cynocephalus atlanticus. [This tooth, according to Mr. A. Gaudry, who kindly examined it, indicates a monkey much larger than the extant Barbary ape [Macaca sylvanus] of Algeria; moreover, it presents characters which recall nearly exactly those of Cynocephalus porcarius [now Papio ursinus], Desm., today restricted to southern Africa. We designate this monkey, provisionally at least, under the name Cynocephalus atlanticus."] (The original uses the term "singe", which in context we translate as "monkey".) The figure legend says crown and internal (lingual) views, but in fact only the external (buccal) view is shown. The tooth has only a slight distal projection but not the hypoconulid lobe which would indicate a third lower molar. The tooth was accessioned into the paleontology collections of the Muséum national d'Histoire naturelle in Paris, at first without a formal number but later as MNHN-F AJO 001.

2. The first mention of the Aïn Jourdel specimen after Thomas (1884) was by Romer (1928), who included Papio atlanticus in a faunal list. Hill (1970: 357-358) showed Thomas's buccal view of the tooth alongside those of the lower third molars of Papio and Mandrillus. He noted that the crown was "hypsodont" [actually mesodont] with "deep vertical grooves between mesial and distal pairs of cusps", which suggested that "an allocation to Theropithecini [Theropithecus in today's usage] would be more appropriate."

3. In his unpublished dissertation, Delson (1973) stated that the Ain Jourdel specimen could be identified as Theropithecus and then, in a list of circum-Mediterranean fossil cercopithecids, Delson (1974: 133) included Cynocephalus atlanticus under the heading Theropithecus sp. The specimen was termed Theropithecus sp. indet. by Szalay \& Delson (1979: 374). Geraads (1980: 82) noted that Theropithecus (Simopithecus) atlanticus was the first fossil species of this genus ever described and suggested that this nomen might be used for North African fossils (from Thomas Quarries and perhaps Tighennif [formerly Ternifine]) or might even be the senior synonym of Theropithecus (Simopithecus) oswaldi. The Aïn Jourdel tooth was briefly discussed as Theropithecus atlanticus by Geraads (1987: 22), while Raynal et al. (1990) suggested the taxon's presence in the first report of the fauna from Ahl al Oughlam, Morocco. 
4. The proceedings of a 1989 conference on the evolution of Theropithecus were published as a book (Jablonski, 1993), with numerous discussions of the fossil record. Delson (1993: 169, figs. 5.4, 5.5) described and illustrated the Aïn Jourdel tooth in detail, noting that it had a distinctive shape of the lingual notch between the cusps; he termed it Theropithecus sp. indet. In addition, Delson (1993: 183-184) recognized the potential nomenclatural disturbance that recognition of Theropithecus atlanticus as a senior synonym of Theropithecus oswaldi might cause, and wrote that he would make a formal request to the ICZN for suppression, but that was not done until now. He further noted that "Pursuant to the Code, current terminology may be continued pending a ruling." Pickford (1993) included Theropithecus atlanticus in his discussion of fossil species, while Delson et al. (1993: 501) catalogued most known fossil specimens of Theropithecus and listed "Cynocephalus atlanticus" but declined to allocate it to a known species. Other authors (e.g., Eck, 1993; Jablonski, 1993; Leakey, 1993) did not mention the taxon at all. Alemseged \& Geraads (1998: 610, figs. 1-3) described numerous fossil specimens from Ahl al Oughlam, which they referred to Theropithecus atlanticus, listing additional supposedly diagnostic features to distinguish it from Theropithecus oswaldi.

5. Following the work of Alemseged \& Geraads (1998), a limited number of other authors have recognized Theropithecus atlanticus as a distinct taxon. Delson et al. (2000b: 75) listed Theropithecus "atlanticus" from Ahl al Oughlam in a table of estimated mass but in the text, they were not certain of its specific distinction. They wrote (Delson et al., 2000b: 80) that it "may represent a population transitional between $T$. darti and $T$. oswaldi that shows some distinctions due to geographic isolation", echoing the view of Alemseged \& Geraads (1998). Frost \& Delson (2002: 714) discussed the nomenclatural priority of Theropithecus atlanticus over Theropithecus oswaldi and noted that it was unclear whether the former was a synonym of, or specifically distinct from, the latter. They thought that the Ahl al Oughlam sample could fit within the known variation of T. oswaldi, while Alemseged \& Geraads (1998) did not. Thus, Frost \& Delson (2002: 714) declined to recognize Theropithecus atlanticus "for the sake of clarity", but did not "imply the specific distinction of T. atlanticus." The majority of later authors did not even mention Theropithecus atlanticus (see para. 11 and list in Appendix), although several have done so: Elton (2002) focused on Theropithecus oswaldi but listed Theropithecus atlanticus as one of six recognized species; Rook et al. (2004) recognized both Theropithecus atlanticus and Theropithecus oswaldi as valid species; Geraads (2006, 2010) again mentioned Theropithecus atlanticus from Ahl al Oughlam in faunal summaries; Hughes et al. (2008) discussed the taxonomic distinction of Theropithecus atlanticus from Theropithecus oswaldi; Geraads et al. (2010) reported Theropithecus atlanticus from Ahl al Oughlam and Theropithecus oswaldi from Thomas Quarries; Sahnouni et al. (2011) included both Theropithecus atlanticus and Theropithecus oswaldi in a figure showing occurrence of taxa at North African sites; and Beaudet et al. (2015) included one specimen of Theropithecus atlanticus from Ahl al Oughlam in an analysis which mainly included Theropithecus oswaldi and other cercopithecid taxa. In an analysis of Theropithecus oswaldi teeth from Spain, Martínez et al. (2020) appears to have followed the ideas of Geraads (1980), although this paper was not cited, when they referred to Theropithecus atlanticus from Ternifine (Algeria) and Thomas Quarries (Morocco). However they mistakenly mentioned the "Pliocene" of Ternifine, citing Alemseged \& Geraads (1998); in fact, the Ternifine (or Tighennif) fossils may be of late Early or early Middle Pleistocene age and are accepted as Theropithecus oswaldi leakeyi by all 
recent authors including Alemseged \& Geraads (1998). All of these authors discussed Theropithecus oswaldi in addition to Theropithecus atlanticus, and none considered the latter taxon the senior synonym of the former; all publications are listed in the Appendix.

6. Andrews (1916: 410, pl. XV, figs. 1-6) named Simopithecus oswaldi for fossil specimens from the site of Kanjera, Kenya. He proposed that two of those specimens were the upper and lower jaw of a single individual and treated them jointly as the "type specimens". They exist in the paleontology collections of the Natural History Museum UK, as M 11537 and M 11539, respectively. Jolly (1972: 15) did not explicitly state that he considered the two specimens to have been derived from different individuals, but he selected the mandible, now NHMUK-P M 11539, as lectotype.

7. The generic name Simopithecus was widely used in the middle third of the 20th century. Hopwood (1934: 547) named Simopithecus leakeyi for a partial lower jaw from Olduvai Gorge (Tanzania, then Tanganyika), differentiating it from Simopithecus oswaldi. Dietrich (1942: 52, fig. 38) named Papio (Simopithecus) serengetensis for a female mandible from the Vogel River area (now Laetoli), also referring to Simopithecus oswaldi while treating that genus as a subgenus of the extant Papio. Broom \& Jensen (1946: 340, figs. 1-2) named Papio darti for a partial lower jaw from Makapan (South Africa). Freedman (1957) reviewed the fossil Cercopithecoidea of South Africa, with notes on fossils from eastern Africa. He recognized that "Papio" darti belonged with Simopithecus and defined the new species Simopithecus danieli (Freedman, 1957: fig. 92) from Swartkrans (South Africa), comparing both taxa to S. oswaldi.

8. Leakey \& Whitworth (1958) reviewed the systematics of Simopithecus and included S. leakeyi, S. serengetensis, S. darti and S. danieli within S. oswaldi, recognizing that some of those samples might be recognized at the subspecific level. They proposed two other nomina for subspecies of Simopithecus oswaldi, but no individual specimens were included for either taxon. S. o. mariae was named for specimens from Olorgesailie, Kenya, and $S$. o. olduvaiensis for material from the lowest horizons at Olduvai, said to be older and smaller than S. leakeyi. One specimen was illustrated (pl. VII, fig. 6) as an example of $S$. o. mariae, and it can be identified as KNM-OG 002, which is the same jaw that Jolly (1972: 96 [see para. 9]) selected as holotype (not a lectotype as it was the only specimen in the type series). Five specimens were illustrated (pl. VII, figs. 2-5, 7) as examples (syntypes) of $S$. o. olduvaiensis, and one of these can be readily identified (and is here selected as lectotype) as NHMUK-P M 14953 (fig. 4), but the others are not definite. Leakey \& Whitworth (1958) also named Simopithecus jonathani for a very large mandible from the upper levels at Olduvai, distinguishing it from Simopithecus oswaldi. Singer (1962) discussed fossils from Hopefield (= Elandsfontein), South Africa, proposing the name Simopithecus oswaldi hopefieldensis and considering it and the previously named South African taxa $S$. o. darti and S. o. danieli as regional subspecies of Simopithecus oswaldi. No holotype was selected but among the syntypes is the partial mandible SAM 3409 (fig. 3 b-d), which is here selected as the lectotype of Simopithecus oswaldi hopefieldensis.

9. Jolly (1972) undertook a major revision of Simopithecus, beginning with the recognition that it was closely related to the extant Theropithecus and considering it a subgenus; he did not mention Cynocephalus atlanticus. As noted above (see para. 8), he selected a lectotype for Theropithecus (Simopithecus) oswaldi from the two specimens mentioned by Andrews (1916). Jolly (1972: 96) selected a holotype for T. (S.) o. mariae from the Olorgesailie sample, and he formally recognized $T$. (S.) o. leakeyi (in which he 
included S. o. olduvaiensis, S. jonathani and probably the Hopefield sample), as well as $T$. (S.) darti darti and T. (S.) darti danieli. Freedman (1976) considered a number of newly recovered South African fossils and followed most of Jolly's (1972) suggestions, although he considered Simopithecus generically distinct from Theropithecus. He recognized the same species and subspecies, formally including the Hopefield sample as Simopithecus darti hopefieldensis. Dechow \& Singer (1984) later discussed the Hopefield material again and declined to recognize a nomen for it at all.

10. Szalay \& Delson (1979: 374), as part of their review of all then-known fossil primates, accepted Jolly's (1972) generic taxonomy and included almost all of the abovementioned populations (and species-group taxa) within Theropithecus (Simopithecus) oswaldi. Only T. (S.) darti was held aside as a species distinct from $T$. (S.) oswaldi on morphological grounds. Delson (1984) and later authors dropped the use of Simopithecus for fossil Theropithecus. Leakey (1993) reviewed the Theropithecus remains from the Turkana Basin of northern Kenya and southern Ethiopia. She argued that Theropithecus darti was best considered as another subspecies of Theropithecus oswaldi, a suggestion which was discussed by several authors in the same book: Jablonski (1993) accepted that view, while Eck (1993) and Delson (1993) retained Theropithecus darti as a distinct species. Most later authors (starting with Frost \& Delson, 2002) also followed Leakey's (1993) approach, although Jablonski \& Frost (2010: 417) retained Theropithecus darti as a separate species.

11. A partial list of publications written since Alemseged \& Geraads (1998) advocated the use of Theropithecus atlanticus, which recognized Theropithecus oswaldi as part of their analyses but did not discuss Theropithecus atlanticus at all, is provided in the Appendix.

12. Cynocephalus atlanticus was proposed before 1899, but as discussed above in paras. 4 and 5 , the name has been employed as valid several times since then. Thus, this name does not fulfill the requirements of Article 23.9.1.1 of the Code to invoke prevailing usage. If this name is retained as the primary synonym in cases where Cynocephalus atlanticus is considered a subjective synonym of Simopithecus oswaldi, significant confusion would result in the literature of primate paleontology, as well as in human and broader mammalian paleontology of the Pliocene and Pleistocene of Africa. Theropithecus is a common to dominant member of the extinct primate community across Africa after 4 million years ago (Jablonski \& Frost, 2010; Frost et al., 2020) and often co-occurs with extinct humans (HominINI); Theropithecus fossils are also known rarely across Eurasia (Roberts et al., 2014). Most fossil samples are currently included in Theropithecus oswaldi (Andrews, 1916), which is often divided into chrono-geographical subspecies. Since 1998, when the name Cynocephalus atlanticus Thomas, 1884, was used for fossils other than the holotype, this species name has only been used 11 times (always in addition to Theropithecus oswaldi), while Simopithecus oswaldi Andrews, 1916, was considered a valid and widespread taxon in 70 publications listed in the Appendix. In the interest of nomenclatural stability, it is therefore necessary to invoke Art. 23.9.3 and request the Commission to use its Plenary Power to maintain common usage and conserve the widely used species-level nomen Simopithecus oswaldi Andrews, 1916 [now Theropithecus oswaldi (Andrews, 1916)] by conditional reversal of precedence with Cynocephalus atlanticus Thomas, 1884. As a result, should an author determine that Theropithecus atlanticus is a subjective synonym of Theropithecus oswaldi, the former nomen would either not be the valid name of the species or could be used for a 
subspecies of the latter different from the nominotypical one. If they are not considered conspecific, Theropithecus atlanticus would of course be a valid nomen.

13. The International Commission on Zoological Nomenclature is accordingly asked:

(1) to use its plenary power to give the specific name oswaldi Andrews, 1916, as published in the binomen Simopithecus oswaldi, precedence over the specific name atlanticus Thomas, 1884, as published in the binomen Cynocephalus atlanticus, whenever the two are considered synonyms;

(2) to place on the Official List of Specific Names in Zoology the following names:

(a) oswaldi Andrews, 1916, as published in the binomen Simopithecus oswaldi, with the endorsement that it is to be given precedence over the name atlanticus Thomas, 1884, as published in the binomen Cynocephalus atlanticus whenever the two are considered synonyms, as ruled in (1) above; and

(b) atlanticus Thomas, 1884, as published in the binomen Cynocephalus atlanticus, with the endorsement that it is not to be given priority over the name oswaldi Andrews, 1916, as published in the binomen Simopithecus oswaldi, whenever the two are considered synonyms, as ruled in (1) above.

\section{Acknowledgements}

We thank ICZN Executive Secretary Gwynne Lim, BZN Editor Neal Evenhuis and two anonymous reviewers for helpful suggestions on an earlier version.

\section{References}

Alemseged Z, Geraads D (1998) Theropithecus atlanticus (Thomas, 1884) (Primates: Cercopithecidae) from the late Pliocene of Ahl al Oughlam, Casablanca, Morocco. Journal of Human Evolution 34: 609-621.

Andrews CW (1916) Note on a new baboon (Simopithecus oswaldi, gen. et sp. n.) from the (?) Pliocene of British East Africa. Annals and Magazine of Natural History (8) 18: 410-419.

Broom R (1937) On some new Pleistocene mammals from limestone caves of the Transvaal. South African Journal of Science 33: 750-768.

Broom R (1940) The South African Pleistocene cercopithecid apes. Annals of the Transvaal Museum 20: 89-100.

Broom R, Jensen JS (1946) A new fossil baboon from the caves at Potgietersrust. Annals of the Transvaal Museum 20: 337-340.

Broom R, Robinson JT (1949) A new type of fossil baboon, Gorgopithecus major. Proceedings of the Zoological Society of London 119: 379-387.

Dechow PC, Singer R (1984) Additional fossil Theropithecus from Hopefield, South Africa: A comparison with other African sites and a reevaluation of its taxonomic status. American Journal of Physical Anthropology 63: 405-435.

Delson E (1973) Fossil colobine monkeys of the circum-Mediterranean region and the evolutionary history of the Cercopithecidae (Primates, Mammalia). Unpublished doctoral dissertation, Columbia University, New York, 856 pp.

Delson E (1974) Preliminary review of cercopithecid distribution in the circum-Mediterranean region. Mémoires du Bureau des Recherches Géologiques et Minières 78: 131-135.

Delson E (1984) Cercopithecid biochronology of the African Plio-Pleistocene: correlation among eastern and southern hominid-bearing localities. Courier Forschungs-Institut Senckenberg 69: 199-218. 
Delson E (1993) Theropithecus fossils from Africa and India and the taxonomy of the genus [pp. 157-189]. In: Jablonski NG (Ed), Theropithecus: The rise and fall of a primate genus. Cambridge University Press, Cambridge.

Delson E, Eck GG, Leakey MG, Jablonski NG (1993) A partial catalogue of fossil remains of Theropithecus [pp. 499-525]. In: Jablonski NG (Ed), Theropithecus: The rise and fall of a primate genus. Cambridge University Press, Cambridge.

Dietrich WO (1942) Ältestquartäre Säugetiere aus der südlichen Serengeti, Deutsch-Ostafrika. Palaeontographica A 94: 44-75.

Eck GG (1993) Theropithecus darti from the Hadar Formation, Ethiopia [pp. 15-83]. In Jablonski NG (Ed), Theropithecus: The rise and fall of a primate genus. Cambridge University Press, Cambridge.

Freedman L (1957) The fossil Cercopithecoidea of South Africa. Annals of the Transvaal Museum 23: $121-262$.

Freedman L (1976) South African fossil Cercopithecoidea: A re-assessment including a description of new material from Makapansgat, Sterkfontein and Taung. Journal of Human Evolution 5: 297-315.

Frost SR, Delson, E (2002) Fossil Cercopithecidae from the Hadar Formation and surrounding areas of the Afar Depression, Ethiopia. Journal of Human Evolution 43: 687-748.

Geoffroy Saint-Hilaire I (1843) Description des Mammifères nouveaux ou imparfaitement connus de la collection du Muséum d'histoire naturelle et remarques sur la classification et les caractères des Mammifères. Premier mémoire. Famille des singes. Archives du Muséum d'Histoire Naturelle, Paris 2: 485-592.

Geraads D (1980) La faune des sites à Homo erectus des carrières Thomas (Casablanca, Maroc). Quaternaria 22: 65-94.

Geraads D (1987) Dating the northern African cercopithecid fossil record. Human Evolution 2: $19-27$.

Hill WCO (1970) Primates: Comparative anatomy and taxonomy. VIII. Cynopithecinae: Papio, Mandrillus, Theropithecus. The University Press, Edinburgh, xx +680 pp., 36 pls., 12 maps.

Hopwood AT (1934) New fossil mammals from Olduvai, Tanganyika Territory. Annals and Magazine of Natural History (10) 14: 546-547.

Jablonski NG (1993) The Phylogeny of Theropithecus [pp. 209-224]. In: Jablonski NG (Ed), Theropithecus: Rise and fall of a primate genus. Cambridge University Press, Cambridge.

Jablonski NG (Ed) (1993) Theropithecus: Rise and fall of a primate genus. Cambridge University Press, Cambridge, $x v i+536 \mathrm{pp}$

Jablonski NG, Leakey MG, Kiarie C, Antón M (2002) A new skeleton of Theropithecus brumpti (Primates: Cercopithecidae) from Lomekwi, West Turkana, Kenya. Journal of Human Evolution 43: 887-923.

Jablonski NG, Frost SR (2010) Cercopithecoidea [pp. 393-428]. In: Werdelin L, Sanders WL (Eds), Cenozoic Mammals of Africa. University of California Press, Berkeley.

Jolly CJ (1972) The classification and natural history of Theropithecus (Simopithecus) (Andrews, 1916), baboons of the African Plio-Pleistocene. Bulletin of the British Museum (Natural History), Geology 22: 1-123.

Leakey LSB, Whitworth T (1958) Notes on the genus Simopithecus with a description of a new species from Olduvai. Coryndon Memorial Museum Occasional Papers 6: 3-14.

Leakey MG (1993) Evolution of Theropithecus in the Turkana Basin [pp. 85-123]. In: Jablonski NG (Ed), Theropithecus: The rise and fall of a primate genus. Cambridge University Press, Cambridge.

Pickford M (1993) Climatic change, biogeography, and Theropithecus [pp. 227-243]. In: Jablonski NG (Ed), Theropithecus: The rise and fall of a primate genus. Cambridge University Press, Cambridge.

Raynal JP, Texier JP, Geraads D, Sbihi-Alaoui FZ (1990) Un nouveau gisement paléontologique plio-pléistocène en Afrique du Nord : Ahl Al Oughlam (ancienne carrière Deprez) à Casablanca 
(Maroc). Comptes Rendus de I'Academie des Sciences Paris 310: 315-320.

Romer AS (1928) Pleistocene mammals of Algeria. Bulletin of the Logan Museum, Beloit 1: 80-163.

Rüppell E (1835) Neue Wirbelthiere zu der Fauna von Abyssinien gehörig. Säugetiere. Sigmund Schmerber, Frankfurt am Main.

Singer R (1962) Simopithecus from Hopefield, South Africa. Bibliotheca Primatologica 1: 43-70.

Szalay FS, Delson E (1979) Evolutionary history of the Primates. Academic Press, New York, xiv $+580 \mathrm{pp}$.

Thomas P (1884) Recherches stratigraphiques et géologiques sur quelques formations d'eau douce de l'Algérie. Mémoires de la Société Géologique de France (3) 3 (2): 1-53.

Acknowledgement of receipt of this application was published in BZN 78: 3.

Comments on this case are invited for publication (subject to editing) in the Bulletin; they should be sent to the Secretariat, International Commission on Zoological Nomenclature, c/o Lee Kong Chian Natural History Museum, 2 Conservatory Drive, Singapore 117377, Republic of Singapore (e-mail: iczn@nus.edu.sg). 


\section{Appendix}

\section{Publications since 1998 including Theropithecus atlanticus as a valid species (but also including Theropithecus oswaldi):}

Beaudet A, Zanolli C, Engda Redae B, Endalamaw M, Braga J, Macchiarelli R (2015) A new cercopithecoid dentognathic specimen attributed to Theropithecus from the late Early Pleistocene (c. $1 \mathrm{Ma}$ ) deposits of Simbiro, at Melka Kunture, Ethiopian highlands. Comptes Rendus Palevol 14: 657-669.

Delson E, Terranova CJ, Jungers WL, Sargis EJ, Jablonski NG, Dechow PC (2000b) Body mass in Cercopithecidae (Primates, Mammalia): estimation and scaling in extinct and extant taxa. Anthropological Papers of the American Museum of Natural History 83: 1-159.

Elton S (2002) A reappraisal of the locomotion and habitat preference of Theropithecus oswaldi. Folia Primatologica 73: 252-280.

Geraads D (2006) The late Pliocene locality of Ahl al Oughlam, Morocco: vertebrate fauna and interpretation. Transactions of the Royal Society of South Africa 61: 97-102.

Geraads D (2010) Biochronologie mammalienne du Quaternaire du Maroc atlantique, dans son cadre régional. L'Anthropologie 114: 324-340.

Geraads D, Raynal JP, Sbihi Alaoui FZ (2010) Mammalian faunas from the Pliocene and Pleistocene of Casablanca (Morocco). Historical Biology 22: 275-285.

Hughes JK, Elton S, O'Regan HJ (2008) Theropithecus and 'out of Africa' dispersal in the PlioPleistocene. Journal of Human Evolution 54: 43-77.

Martínez LM, Estebaranz-Sánchez F, Ferràndez-Cañadell C, Romero A, Ribot F, Galbany J, Gibert L, Pérez-Pérez A (2020) Buccal dental-microwear and feeding ecology of Early Pleistocene Theropithecus oswaldi from Cueva Victoria (Spain). Journal of Human Evolution 142: 102736.

Rook L, Martínez-Navarro B, Howell FC (2004) Occurrence of Theropithecus sp. in the Late Villafranchian of Southern Italy and implication for Early Pleistocene "out of Africa" dispersals. Journal of Human Evolution 47: 267-277.

Sahnouni M, Van der Made J, Everett M (2011) Ecological background to Plio-Pleistocene hominin occupation in North Africa: the vertebrate faunas from Ain Boucherit, Ain Hanech and El-Kherba, and paleosol stable-carbon-isotope studies from El-Kherba, Algeria. Quaternary Science Reviews 30: 1303-1317.

Turner A, Bishop LC, Denys C, McKee JK (1999) A locality-based listing of African PlioPleistocene mammals [pp. 369-399]. In: Bromage TG, Schrenk F (Eds), African biogeography, climate change, and human evolution. Oxford University Press, Oxford.

\section{Publications since 1998 including Theropithecus oswaldi but not Theropithecus atlanticus as a distinct species:}

Adams JW, Herries AIR, Hemingway J, Kegley AD, Kgasi L, Hopley P, Reade H, Potze S, Thackeray JF (2010) Initial fossil discoveries from Hoogland, a new Pliocene primate-bearing karstic system in Gauteng Province, South Africa. Journal of Human Evolution 59: 685-691.

Alba DM, Colombero S, Delfino M, Martínez-Navarro B, Pavia M, Rook L (2014) A thorny question: The taxonomic identity of the Pirro Nord cervical vertebrae revisited. Journal of Human Evolution 78: 92-106.

Alemseged Z, Geraads D (2000) A new Middle Pleistocene fauna from the Busidima-Telalak region of the Afar, Ethiopia. Comptes Rendus de 1'Académie des Sciences (IIA) 331: 549-556.

Alemseged Z (2015) Stable isotopes serving as a checkpoint. Proceedings of the National Academy of Sciences USA 112: 12232-12233.

Beaudet A, Dumoncel J, deBeer F, Duployer B, Durrleman S, Gilissen E, Hoffman J, Tenailleau C, Thackeray JF, Braga J (2016) Morphoarchitectural variation in South African fossil cercopithecoid endocasts. Journal of Human Evolution 101: 65-78. 
Bedaso Z, Wynn JG, Alemseged Z, Geraads D (2010) Paleoenvironmental reconstruction of the Asbole fauna (Busidima Formation, Afar, Ethiopia) using stable isotopes. Geobios 43: 165-177.

Belmaker M (2002) First evidence of the presence of Theropithecus sp. in the Southern Levant. Israel. Israel Journal of Zoology 48 (2): 165.

Belmaker M (2010). The presence of a large cercopithecine (cf. Theropithecus sp.) in the 'Ubeidiya formation (Early Pleistocene, Israel). Journal of Human Evolution 58: 79-89.

Benefit B (1999) Biogeography, dietary specialization and the diversification of African PlioPleistocene monkeys [pp. 172-188]. In: Bromage TG, Schrenk F (Eds), African biogeography, climate change, and human evolution. Oxford University Press, Oxford.

Cerling TE, Chritz KL, Jablonski NG, Leakey MG, Manthi FK (2013) Diet of Theropithecus from 4 to $1 \mathrm{Ma}$ in Kenya. Proceedings of the National Academy of Sciences USA 110: 10507-10512.

Codron D, Luyt J, Lee-Thorp JA, Sponheimer M, de Ruiter D, Codron J (2005) Utilization of savanna-based resources by Plio-Pleistocene baboons. South African Journal of Science 101: 245-248.

Delson E, Tattersall I, Van Couvering JA, Brooks AS (Eds) (2000a) Encyclopedia of human evolution and prehistory. $2^{\text {nd }}$ Edition. Garland Publishing, New York, xlv $+753 \mathrm{pp}$.

DeSilva JM, Steininger CM, Patel BA (2013) Cercopithecoid primate postcranial fossils from Cooper's D, South Africa. Geobios 46: 381-394.

Elton S (2001) Locomotor and habitat classifications of cercopithecoid postcranial material from Sterkfontein Member 4, Bolt's Farm and Swartkrans Member 1 and 2, South Africa. Palaeontologia Africana 37: 115-126.

Elton S (2007) Environmental correlates of the cercopithecoid radiations. Folia Primatologica 78: $344-364$.

Elton S (2012) Impacts of environmental change and community ecology on the composition and diversity of the southern African monkey fauna from the Plio-Pleistocene to the present [pp. 471-486]. In: Reynolds SC, Gallagher A (Eds), African genesis: Perspectives on hominin evolution. Cambridge University Press, Cambridge.

Elton S, Barham L, Andrews PJ, Sambrook Smith GH (2003) Pliocene femur of Theropithecus from the Luangwa Valley, Zambia. Journal of Human Evolution 44: 133-139.

Elton S, Dunn J (2020) Baboon biogeography, divergence, and evolution: Morphological and paleoecological perspectives. Journal of Human Evolution 145: 102799.

Ferrández-Cañadell C, Ribot F, Gibert L (2014) New fossil teeth of Theropithecus oswaldi (Cercopithecoidea) from the Early Pleistocene at Cueva Victoria (SE Spain). Journal of Human Evolution 74: 55-66.

Fleagle JG (2013) Primate adaptation and evolution. $3^{\text {rd }}$ Edition. Academic Press, New York, $x$ $+423 \mathrm{pp}$.

Folinsbee KE, Reisz RR (2013) New craniodental fossils of papionin monkeys from Cooper's D, South Africa. American Journal of Physical Anthropology 151: 613-629.

Fourie NH, Lee-Thorp JA, Ackermann RR (2008) Biogeochemical and craniometric investigation of dietary ecology, niche separation and taxonomy of Plio-Pleistocene cercopithecoids from the Makapansgat Limeworks. American Journal of Physical Anthropology 135: 121-135.

Frost SR (2007a) Fossil Cercopithecidae from the Middle Pleistocene Dawaitoli Formation, Middle Awash Valley, Afar Region, Ethiopia. American Journal of Physical Anthropology 134: 460-467.

Frost SR (2007b) African Pliocene and Plistocene cercopithecid evolution and global climatic change [pp. 51-76]. In: Bobe R, Alemseged Z, Behrensmeyer AK (Eds), Hominid environments in the East African Pliocene: An assessment of the faunal evidence. Springer, Dordrecht.

Frost SR (2014) Fossil Cercopithecidae of the Konso Formation. Bulletin The University Museum, The University of Tokyo 47: 41-72, 91-96.

Frost SR, Delson, E (2002) Fossil Cercopithecidae from the Hadar Formation and surrounding areas of the Afar Depression, Ethiopia. Journal of Human Evolution 43: 687-748.

Frost SR, Plummer T, Bishop LC, Ditchfield P, Ferraro J, Hicks J (2003) Partial cranium of 
Cercopithecoides kimeui Leakey, 1982 from Rawi Gully, southwestern Kenya. American Journal of Physical Anthropology 122: 191-199.

Frost SR, Alemseged Z (2007) Middle Pleistocene fossil Cercopithecidae from Asbole, Afar Region, Ethiopia. Journal of Human Evolution 53: 227-259.

Frost SR, Kullmer O (2008) Cercopithecidae from the Pliocene Chiwondo Beds, Malawi-rift. Geobios 41: 743-749.

Frost SR, Haile-Selassie Y, Hlusko LG (2009) Cercopithecidae [pp. 135-158]. In: Haile-Selassie Y, WoldeGabriel G (Eds), Ardipithecus kadabba. Late Miocene evidence from the Middle Awash, Ethiopia. University of California Press, Berkeley.

Frost SR, Schwartz HL, Giemsch L, Morgan LE, Renne PR, Wildgoose M, Saanane C, Schrenk F, Harvati K (2012) Refined age estimates and Paleoanthropological investigation of the Manyara Beds, Tanzania. Journal of Anthropological Sciences 90: 1-12.

Frost SR, Jablonski NG, Haile-Selassie Y (2014) Early Pliocene Cercopithecidae from WoransoMille (Central Afar, Ethiopia) and the origins of the Theropithecus oswaldi lineage. Journal of Human Evolution 76: 39-53.

Frost SR, Saanane C, Starkovich BM, Schwartz H, Schrenk F, Harvati K (2017) New cranium of the large cercopithecid primate Theropithecus oswaldi leakeyi (Hopwood, 1934) from the paleoanthropological site of Makuyuni, Tanzania. Journal of Human Evolution 109: 46-56.

Frost SR, Gilbert CC, Delson E (2018) Review of Cercopithecidae from Upper Laetolil Beds, Tanzania, indicates presence of Theropithecus: biogeographic and taxonomic implications. American Journal of Physical Anthropology 165 (S66): 90-91.

Frost SR, Ward CV, Manthi FK, Plavcan JM (2020) Cercopithecid fossils from Kanapoi, West Turkana, Kenya (2007-2015). Journal of Human Evolution 140: 102642.

Geraads D (2016) Pleistocene Carnivora (Mammalia) from Tighennif (Ternifine), Algeria. Geobios 49: 445-458.

Geraads D, de Bonis L (2020) First record of Theropithecus (Cercopithecidae) from the Republic of Djibouti. Journal of Human Evolution 138: 102686.

Gilbert CC (2007) Craniomandibular morphology supporting the diphyletic origin of mangabeys and a new genus of the Cercocebus/Mandrillus clade, Procercocebus. Journal of Human Evolution 53: 69-102.

Gilbert CC (2013) Cladistic analysis of extant and fossil African papionins using craniodental data. Journal of Human Evolution 64: 399-433.

Gilbert CC, Frost SR, Delson E (2014) African Plio-Pleistocene biochronology: a reassessment using cercopithecoid taxa. American Journal of Physical Anthropology 153 (S58): 124.

Gilbert CC, Frost SR, Delson E (2016) Reassessment of the Olduvai Bed I cercopithecoids: a new biochronological and biogeographical link to the South African fossil record. Journal of Human Evolution 92: 50-59.

Gilbert WH, Frost SR (2008) Cercopithecidae [pp. 115-132]. In: Gilbert WH, Asfaw B (Eds), Homo erectus: Pleistocene evidence from the Middle Awash, Ethiopia. University of California Press, Berkeley.

Gommery D, DaCosta LB (2016) Les primates non-humains pliocènes et plio-pléistocènes d'Afrique du Sud. Revue de Primatologie 7: doi: 10.4000/primatologie.2698

Gundling T, Hill A (2000) Geological context of fossil Cercopithecoidea from eastern Africa [pp. 180-213]. In: Whitehead PF, Jolly CJ (Eds), Old World monkeys. Cambridge University Press, Cambridge.

Harris JM, Leakey MG, Cerling TE (2003) Early Pliocene tetrapod remains from Kanapoi, Lake Turkana Basin, Kenya. Contributions in Science, Natural History Museum of Los Angeles County, Los Angeles 498:39-114.

Harrison T (2011) Cercopithecids (Cercopithecidae, Primates) [pp. 83-139]. In: Harrison T (Ed), Paleontology and geology of Laetoli: Human evolution in context: Fossil hominins and the associated fauna. Vol. 2. Springer, Dordrecht.

Howell FC (1999) Introduction [to Part III, fossil faunas] [pp. 167-171]. In: Bromage TG, Schrenk 
F (Eds), African biogeography, climate change, and human evolution. Oxford University Press, Oxford.

Jablonski NG (2002) Fossil Old World monkeys: The late Neogene radiation [pp. 255-299]. In: Hartwig WC (Ed), The primate fossil record. Cambridge University Press, Cambridge.

Jablonski NG, Leakey MG, Antón M (2008) Systematic paleontology of the cercopithecines [pp. 103-300]. In: Jablonski NG, Leakey MG (Eds), Koobi Fora research project: Volume 6. The fossil monkeys. California Academy of Sciences, San Francisco.

Jablonski NG, Frost SR (2010) Cercopithecoidea [pp. 393-428]. In: Werdelin L, Sanders WL (Eds), Cenozoic mammals of Africa. University of California Press, Berkeley.

Kahlke RD, García N, Kostopoulos DS, Lacombat F, Lister AM, Mazza PP, Spassov N Titov VV (2011) Western Palaearctic palaeoenvironmental conditions during the Early and early Middle Pleistocene inferred from large mammal communities, and implications for hominin dispersal in Europe. Quaternary Science Reviews 30: 1368-1395.

Kullmer O, Sandrock O, Kupczik K, Frost SR, Volpato V, Bromage TG, Schrenk F (2011) New primate remains from Mwenirondo, Chiwondo Beds in northern Malawi. Journal of Human Evolution 61: 617-623.

Kuman K, Clarke RJ (2000) Stratigraphy, artefact industries and hominid associations for Sterkfontein, Member 5. Journal of Human Evolution 38: 827-847.

Leakey MG, MF Teaford, Ward CV (2003) Cercopithecidae from Lothagam [pp. 201-248]. In: Leakey MG , Harris J M (Eds), Lothagam: The dawn of humanity in eastern Africa. Columbia University Press, New York.

Levin NE, Haile-Selassie Y, Frost SR, Saylor BZ (2015) Dietary change among hominins and cercopithecids in Ethiopia during the early Pliocene. Proceedings of the National Academy of Sciences USA 112: 12304-12309.

Martin F, Plastiras CA, Merceron G, Souron A, Boisserie JR (2018). Dietary niches of terrestrial cercopithecines from the Plio-Pleistocene Shungura Formation, Ethiopia: evidence from dental microwear texture analysis. Scientific Reports 8: 14052.

Patel BA, Gilbert CC, Ericson KE (2007) Cercopithecoid cervical vertebral morphology and implications for the presence of Theropithecus in early Pleistocene Europe. Journal of Human Evolution 52: 113-129.

Patnaik R, Cerling TE, Uno KT, Fleagle JG (2014) Diet and habitat of Siwalik primates Indopithecus, Sivaladapis and Theropithecus. Annales Zoologici Fennici 51: 123-142.

Pugh KD, Gilbert CC (2018) Phylogenetic relationships of living and fossil African papionins: combined evidence from morphology and molecules. Journal of Human Evolution 123: 35-51.

Raynal JP, Sbihi-Alaoui FZ, Mohib A, El Graoui M, Lefèvre D, Texier JP, Hublin JJ, Smith T, Tafforeau P, Zouak M, Grün R, Rhodes EJ, Eggins S, Daujeard C, Fernandes P, Gallotti R, Hossini S, Queffelec A (2010) Hominid cave at Thomas Quarry I (Casablanca, Morocco): Recent findings and their context. Quaternary International 223-224: 369-382.

Rector AL, Vergamini M (2018) Forelimb morphology and substrate use in extant Cercopithecidae and the fossil primate community of the Hadar sequence, Ethiopia. Journal of Human Evolution 123: 70-83.

Roberts P, Delson E, Miracle P, Ditchfield P, Roberts RG, Jacobs Z, Blinkhorn J, Ciochon RL, Fleagle JG, Frost SR, Gilbert CG, Gunnell GG, Harrison T, Korisettar R, Petraglia MD (2014) Continuity of mammalian fauna over the last 200,000 years in the Indian Subcontinent. Proceedings of the National Academy of Sciences USA 111: 5848-5853.

Rook L, Ghinassi M, Libsekal Y, Martínez-Navarro B, Medin T, Papini M (2010) Stratigraphic context and taxonomic assessment of the large cercopithecoid (Primates, Mammalia) from the late Early Pleistocene palaeoanthropological site of Buia (Eritrea). Journal of Human Evolution 59: 692-697.

Rook L, Martínez-Navarro B (2013) The large sized cercopithecoid from Pirro Nord and the importance of Theropithecus in the Early Pleistocene of Europe: faunal marker for hominins dispersal outside Africa. Palaeontographica A 298: 107-112. 
Souron A (2018) Morphology, diet, and stable carbon isotopes: on the diet of Theropithecus and some limits of uniformitarianism in paleoecology. American Journal of Physical Anthropology 166: 261-267.

Van der Merwe NJ, Thackeray JF, Lee-Thorp JA, Luyt J (2003) The carbon isotope ecology and diet of Australopithecus africanus at Sterkfontein, South Africa. Journal of Human Evolution 44: 581-597.

Williams FL, Ackermann RR, Leigh SR (2007) Inferring Plio-Pleistocene southern African biochronology from facial affinities in Parapapio and other fossil papionins. American Journal of Physical Anthropology 132: 163-174. 